\title{
CHARACTERISTICS OF GOOD ENGLISH TEACHERS BASED ON THE PERCEPTION OF THE STUDENTS FROM DIFFERENT LEARNING STYLES AND PERSONALITIES
}

\author{
Fausiah Sriyuliyana \\ State University of Makassar, Indonesia
}

\begin{abstract}
[Title: characteristics of good english teachers based on the perception of the students from different learning styles and personalities] The research aims are (i) Identifying the characteristics of good English teachers in SMAN 3 Sinjai Selatan. (ii) Knowing the characteristics of good English teacher based on the students' learning style. (iii) Knowing the characteristics of good English teacher based on the students' personality. This research was done by using a qualitative approach. The data were collected by using two instruments i.e. questionnaires and in depth interview. The results of this study reveal that (i) The characteristics of good English teacher based on the students' perception in SMAN 3 Sinjai Selatan are categorized into four different categories, namely proficiency, pedagogical (both conceptual and practical), socio-affective and psychological aspect. The last category was the additional category in which age included in and differently from the work of Gi and Hyo (2006) that only specified three categories, namely proficiency, pedagogical and socio-affective skills. (ii) In general, the characteristics of good English teacher based on the students' learning style are dominantly in pedagogical aspect. Visual learners want English teacher who can keep the students' focus and concentration in their learning; auditory learners expect English teacher who can engage the students' motivation and interest toward learning English; and haptic learners propose the English teacher who concerns on the process rather than the achievement of the students in learning. (iii) The characteristics of good English teacher proposed by high school students based on their personality are dominantly on the teacher's pedagogical and socio-affective aspects. Only a few ideas of the students that concern on the teacher's proficiency and psychological aspect.
\end{abstract}

Keywords: Characteristics, Good English Teacher, Learning Styles, Personalities

\section{INTRODUCTION}

Teaching English in non-English teaching countries, like Indonesia, is always interesting and challenging. The quality of English teachers is one of the key of the success in teaching and learning in the classroom. It does not only cover about the proficiency and pedagogical knowledge of the teacher but also some other aspects including socio-affective characteristics to improve the students proficiency in English. Ferguson and Brown (2000) in their investigation to the teacher quality and the students' achievement described that the 
teacher quality gave effects to the students' learning. At least, there are three kinds of the effects given, namely students' academic achievement, love of learning maturity, and career goals. The effects given both short and long term are in the essential development part of the students.

Unfortunately, the performance of the teacher in the classroom does not merely impressive for the whole class. Every student is different in learning and has different expectation of the performance of the teacher. The unwillingness of the student toward the way of the teacher teaching them influences the students' love of learning which has effect to their achievement, including in learning English. The difference of the students can be influenced by internal factors such as the students' learning styles (Montgomery and Groat: 1998) and personalities (Meador: 2014). Different learning styles and different personalities of the students may employ different expectation toward the performance of the teacher in the classroom.

It makes listening the students' voice about good English teacher is important. It is to fill the gap happened between the teachers' expectation to their students and students' expectation to their teachers. Accommodating almost all of the students' expectation toward the positive improvement in learning is something reasonable, even obligatory for a good teacher. Moreover, to do that is possible by listening the students' perception and expectation, including about characteristics of good English teacher for them.

\section{Research Questions}

This study aims at knowing the characteristics of good English teacher based on the students' perceptions. To reach this objective, this study addresses the following research questions: (1) What are the characteristics of good English teachers based on the students' perception in SMAN 3 Sinjai Selatan? (2) How are the characteristics of good English teachers based on the students' learning style? (3) How are the characteristics of good English teachers based on the students' personality? 


\section{METHODS AND PARTICIPANTS}

As a case study that wanted to identify the students' perceptions about the characteristics of good English language teachers in the context of teaching English as a foreign language, this study was designed to get the data from the higher and the lower achiever from all classes in all grades of SMA Negeri 3 Sinjai Selatan. There were 30 subjects participated in this study. They were given questionnaire and then interviewed. Not all the subjects were interviewed, only some of them who had interesting responds in the interview. This study used a purposive sampling, in which the chosen subjects were taken purposively but still ought to fulfill the characteristics needed in this research.

\section{RESULT}

After doing a sort of techniques in collecting data, the results of the study summarized in terms of (1) characteristics of good English teachers; (2) characteristics of good English teachers based on the students learning styles; (3) characteristics of good English teachers based on the students personalities.

\section{Characteristics of Good English Teachers}

Based on the questionnaire result (Appendix $\mathrm{H}$ ), the three categories specified by $\mathrm{Gi}$ and Hyo (2006) identified that not all of the items of those categories favored by the students to indicate good English teacher. Socio-affective skills and pedagogical knowledge dominated the responds of the students, while proficiency was not too much. And among them, socioaffective skills was the most factor that believed by the students could characterized a good English teacher.

From those findings, there were several implications and assumptions that can be achieved. The first, the students perceived that proficiency of the teacher was not important enough for them to do their best in the classroom. The most important thing for them is the ability of the teacher to organize the classroom activities well by their pedagogical knowledge and to interact with their students well by their socio-affective skills. The second, the quality of the teacher, in term of their proficiency was quite difficult for the students to characterize because evaluating their teacher proficiency was not in their level. As the people in the 
place where not too much exposure in English, being able to produce English had been assumed as something great, although it was not as accurate as it should be. The third, the term character in Indonesian culture was closer to affective quality than any other types of qualities.

Based on the analysis of the items of questionnaire to indicate a good English teacher proposed by Gi and Hyo (2006), respond of the students in Appendix E shows that not all the items look favor for the students to indicate a good English teacher.

When most of the items in that questionnaire responded by agree or strongly agree, there are some other items still responded contrarily. In proficiency, knowledge of the teacher to English culture as the item that is for the students not characterizing the quality of the teacher. More students show negative respond, in term of not too much agree toward this item. This phenomenon also can be seen in the part of socio affective of the teacher. In the way teacher interacts to their students in the classroom, the sense of humor of the teacher was characterized negatively. It indicated that having highly sense of humor was not too much important for the students. From this analysis, it implies that some characteristics proposed by Gi and Hyo (2006) not all agree with the expectation of the students as the subjects in this study.

\section{Characteristics of Good English Teachers Based on the Students Learning Styles}

There are several findings identified in this part. In short, all the parts are presented in the following table:

\begin{tabular}{|l|l|}
\hline Categories & Characteristics of Good English teacher \\
\hline 1. Visual & $\begin{array}{l}\text { 1. The teacher must be able to maintain the students' focus or concentration towards the } \\
\text { material learnt } \\
\text { 2. The teacher should apply technique that make the whole class felt being paid attention } \\
\text { by their teacher } \\
\text { 3. Being a high sense of humor is not always good in teaching. The proportionate humor } \\
\text { is the better one. } \\
\text { 4. A teacher must be highly appreciating the time. } \\
\text { 5. The teacher is responsible for keeping the students feeling comfort in learning } \\
\text { 6. Mastery in English especially the materials to teach and deliver them in well organized } \\
\text { 7. Important to give reward to the students' achievement in learning. }\end{array}$ \\
\hline
\end{tabular}




\begin{tabular}{|c|c|}
\hline 2. Auditory & $\begin{array}{l}\text { 1. The teacher must be firm, } \\
\text { 2. The teacher should be creative to get the students' attention } \\
\text { 3. A good English teacher must have a good competence as well as a good performance. } \\
\text { 4. Friendly and patient teacher } \\
\text { 5. The teacher must have a good ability and creativity in engaging the students to be } \\
\text { interested in learning English. } \\
\text { 6. The teacher who gives punishment to their students in order to engage the students to } \\
\text { be motivated in learning } \\
\text { 7. The teacher who provides challenge to the students. }\end{array}$ \\
\hline 3. Haptic & $\begin{array}{l}\text { 1. The teacher who care of their appearance, in terms of the way they dress. } \\
\text { 2. A good teacher should not point the student, but considering the students' ability } \\
\text { before pointing } \\
\text { 3. A good teacher should not only sit down in her/his chair but go around to interact with } \\
\text { their students } \\
\text { 4. A teacher should appreciate the students' answers/responds in their learning } \\
\text { 5. A good teacher should provide media. }\end{array}$ \\
\hline
\end{tabular}

In the following excerpts were taken from the students haptic learning styles:

Researcher : Ok. Do you like the way he teaches you?

UJ : I also like when he is teaching, he never stays and sits on his seat. He always walks around to interact with the students in the classroom. He is not only explaining while sitting.

Researcher : So does he go around?

UJ : Yes, he is controlling the students, therefore we are serius in learning

Researcher : So, when he is controlling, does he also ask the students about their difficulties?

UJ : Yes. When the teacher only sits in fronts of the class the students might be difficult to express their difficulties. Fortunately, he always goes around and enables us to ask him about our difficulty?

Researcher : So is it easier to interact when the teacher around us?

UJ : Yes.

(Interviewing UJ on March 11th, 2014) 


\section{Characteristics of Good English Teachers Based on the Students' Personalities}

There are several findings identified in this part. In short, all the parts are presented in the following table:

\begin{tabular}{|c|c|}
\hline Categories & Characteristics of Good English teacher \\
\hline 1. Extrovert & $\begin{array}{l}\text { 1. The teacher should focused on enriching students' vocabularies, correcting their } \\
\text { pronunciation and building their confidence as well }\end{array}$ \\
\hline & $\begin{array}{l}\text { 2. The teacher should provide samples that closed to the students' live, therefore it can } \\
\text { be more applicable } \\
\text { 3. The teacher should strengthen the role of repetition to ensure the students } \\
\text { comprehension of the material taught }\end{array}$ \\
\hline 2. Introvert & $\begin{array}{l}\text { 1. The teacher ought to be more creative in applying method, especially the method that made } \\
\text { the students easier to understand the material learnt. }\end{array}$ \\
\hline 3. Sensing & $\begin{array}{l}\text { 1. A teacher who can provide materials to the students that contained new information } \\
\text { for them. } \\
2 . \quad \text { The teacher who had louder voice with clearer pronunciation. }\end{array}$ \\
\hline 4. Intuitive & 1. Teacher who appreciate students' effort more than the students' achievement. \\
\hline 5. Thinking & $\begin{array}{l}\text { 1. The teacher who gives chance to the students to practice and to build their English habit in } \\
\text { the classroom }\end{array}$ \\
\hline 6. Feeling & 1. English teacher should perform like friend for their students in the classroom \\
\hline 7. Judging & $\begin{array}{l}\text { 1. A good English teacher should be young teacher, it's by considering the creativity and } \\
\text { information served. } \\
\text { 2. The teacher who organizes the explanation. } \\
\text { 3. The teacher who always provides new information which not included in text-book. }\end{array}$ \\
\hline 8. Perceiving & 1. The teacher should know the character of her/his students \\
\hline
\end{tabular}

Several excerpts and transcriptions presented in the following part are the sources for the above characteristics. Those excerpts and transcriptions are:

"I expect the teacher who can make the students free of being stressful and humorous. Besides that, when explaining, the students easily to catch the points and he/she has louder voice with a clear pronunciation." (Open-ended questionnaire, responded by DD)

Besides that:

Researcher : Ok, are you interested in English?

YSF : Fairly. Fairly interested.

Researcher : Why?

YSF : Because English is difficult. 
Researcher : That makes you not too much interested in English.

YSF : : Difficult but still important, so I only fairly interested in that.

Researcher : Ok, for you, what makes it difficult?

YSF : Hmm. In English, it's different on the way it's written and the way it's pronounced. Besides that, there are a lot of complicated tenses used. It was totally different from Indonesian language.

(Interviewing YSF on March 14th, 2014)

\section{DISSCUSSION}

As presented in the table in the previous part, the student's perception about the characteristics of good English teacher are dominated by the technical ideas. It covers of what the students can see, hear and experience during English class time. Therefore, their perceptions mostly about the pedagogical knowledge of the teacher. When it was viewed closer, for some characteristics of good English teacher mentioned by the students in pedagogical knowledge category, it can be found that those characteristics were more practical and applicable. It is not enough to put them in the level of knowledge which more conceptual but those are more to practical stage of pedagogic aspect.

Some of the characteristics specified by the students as the data in this study were not categorized into those three categories specified by Gi \& Hyo (2006). Those characteristics are (1) the teacher who always gives reward to the students for any achievement in learning English; (2) the teacher who always gives punishment to their student which intended to motivate the students in learning; (3) the teacher who provides challenge for the students in learning; and (4) the teacher of English should be young. In one side, the three former characteristics seem closed to the pedagogical knowledge but in another side those are more detailed or more specific than just a pedagogical knowledge of the teacher. And the last characteristics is the most difficult to categorize. That characteristic is about age. It suggests the new categorization of the characteristics of good English teacher on psychological aspect in which this characteristic included. 
For the student in visual learning style, there were seven additional characteristics stated by the samples to characterize their good English teacher. From those seven characteristics, the subjects seem to put the focus and concentration of the students in learning as the central issue for them. It can be indicated by several characteristic specified. In the first characteristic in the table 4.1 it is clearly mentioned the issues but the other characteristics looked had their own key terms that referred to the focus and concentration in learning. It is just like the key terms about the students need the teacher' attention, the humor must be proportionated, appreciating the allocated time, and keeping the students' feeling comfort. All those keywords realizing the students need to be focus and more concentrate in learning. From this elaborated ideas, the core of the students' expected characteristics of good English teacher based on the visual learning style students is the teacher who can keep the students' focus and concentration toward their English learning in the classroom. It is reasonable for the learners in this kind of learning style to concern more on focusing or concentrating their mind in learning. Based on the view of DePorter \& Hernacki (2002: 85), visual learners need to cluster their understanding in their mind by presenting it by images. And constructing those images needs more concentration and more focus in learning. In the other word, visual learners memorizing or comprehending the material learnt by associating what they are learning and what in their mind. Therefore, the visual learners mostly found taking their seats in the front row.

For the auditory learning style students, the subjects in this study who categorized as the auditory learning styles had contributed to seven characteristics of good English teacher. From those all the seven characteristics mentioned, the core of the students' perception is enhancing the motivation. It also can be identified by referring the keywords in each item of the stated characteristics of good English teacher. The keywords which refer to this idea are teacher provides challenge, teacher gives punishment, teacher has ability and creativity to enhance the students' interest, and teacher must be friendly and patient. Those keywords describe the students' willingness to have a teacher that can enhance their motivation in learning English. By that reason, the central issue of the characteristics of good English 
teacher for the auditory students is the teacher who can enhance the students' motivation and interest in learning English.

Related to Reid (1995: viii-xiii), the auditory learners difficult to learn by any written information. They learn best from context instead of text. They need to express their selves and make a lot of discussion with people in learning. That makes the auditory learner prefer learning with other to self-learning. By this view, it looks reasonable for the auditory learners when need teacher who can make them comfort in learning by keeping their interest and motivation up in learning.

For haptic learners, this study compiled five characteristics of good English teacher based on the perception of the haptic students. From those specified characteristics, the concern to the process than the result of learning seems the core of their voice. It can be indicated by their willingness to have media in learning, prefer a controlling teacher than just a passive teacher, and the teacher who considering the students' ability before asking. From those key points on the students' perception of this category, the haptic learners need a teacher that concern to the students' learning process than just the students' learning achievement. Since the haptic learners need movements in their learning, they do not spend much time neither to make visualization nor to do discussion. They prefer learning by employing action. This idea was proposed by DePorter, Reardon, \& Singer (2000: 168). The haptic learners associating their movement or action with the things they learn to build. By this way, they construct their comprehension. Because they are rather slow in understanding material they need to be appreciated by the process they employ in learning. That's why, it is reasonable to find the haptic learners to need the teachers who appreciate their learning process than their learning result.

\section{CONCLUSIONS}

Based on the research findings and discussion in the previous chapter, the researcher comes to the following conclusions. The characteristics of good English teacher based on the students' perception in SMAN 3 Sinjai Selatan are categorized into four different categories, namely proficiency, pedagogical (both conceptual and practical), socio-affective 
and psychological aspect. The last category was the additional category in which age included in and differently from the work of Gi and Hyo (2006) that only specified three categories, namely proficiency, pedagogical and socio-affective skills. In general, the characteristics of good English teacher based on the students' learning style are dominantly in pedagogical aspect. Specifically, the students show different central issue on the characteristic of good English teacher based on their learning style. Visual learners want English teacher who can keep the students' focus and concentration in their learning; auditory learners expect English teacher who can engage the students' motivation and interest toward learning English; and haptic learners propose the English teacher who concerns on the process rather than the achievement of the students in learning. The characteristics of good English teacher proposed by high school students are dominantly on the teacher's pedagogical and socio-affective aspects. Only a few ideas of the students that concern on the teacher's proficiency and psychological aspect.

\section{References}

Chapuis, Lea. 2003. Pedagogy: Embedding Learning Technologies, Module 1. Australia: Australian Capital Territory Education and Training. An article (http://www.principals.in/uploads/pdf/Pedagogy.pdf_downloaded on January $27^{\text {th }}$, 2014 , at 01.52 )

Dalley, Leanne \& Trim. 2007. Students' Observation and Perception of Teacher Performances in the Classroom. An article. Australian Journal of Teacher Education, Vol. 32, No. 1.2. James Cook University.

Dessus, Philippe. Mandin, Sonia. \& Zampa, Virginia. 2008. What is Teaching? CognitiveBased Tutoring principles for the Design of a Learning Environment. An article. Common Inovation in e-learning, machine learning and humanoid (ICHSL6). Pp. 49-55.

Dunn, R. et al. 2009. Impact of Learning Style Instructional strategies in students' achievemnt and attitude: Perception of educators in Diverse Institution. The Clearing House, January/ February: 135/ 141.

Elbow, Peter H., 1968. The definition of teaching. An article. College English. College English, Vol. 30, No. 3, December 1968, pp. 187-201. National Council of Teachers of English.

Ferguson, Ronald F. \& Brown, Jordana. 2000. 
Certification Test Score, Teacher Quality, and Student Achievement. An article. Analytic Issues in the Assassement of Student Achievement (pp. 133-156). Washington DC: National Center for Educational Statistics.

Gay, Mills \& Airasian. 2006. Educational Research: Competencies for Analysis and Applications. Eight Edition. Ohio: Pearson Merrill Prentice Hall.

Gi, Pyo Park \& Hyo, Woong Lee. 2006. The Characteristics of Effective English Teacher Perceived by High School Teachers and Students in Korea. An Article. Asia Pacific Education Review, 2006, Vol. 7, No. 2, 236-2248. Education Research Institute.

Halberstadt, Amy G., Denham, Susanne A., \& Dunsmore, Julie C. 2001. Affective Social Competence. An Article. (http://www.isce.vt.edu/files/ASC\%20target.pdf downloaded on January 27, 2014, at 02.57) Oxford (UK), Malden (USA): Blackwell Publishers Ltd.

Husain, D. 1999. Learning and Personality Styles in Second Language Acquisition. Unpublished Thesis. Ujung Pandang: Hasanuddin University.

Husain, D. 2011. Fostering Autonomous Learning Inside and Outside the Classroom in Language Learning. Makassar: Badan Penerbit UNM.

Kise, Jane \& Russell, Beth. 2011. Personality Type Applications in Education: Are They Really Problem Students? Bridging Differences through Understanding. An Article. (http://www.personalitypathways.com/MBTI_articles4b.html downloaded on July 8, 2014 at 14.02)

Koehler, Mathew. 2011. Pedagogical Knowledge. TPAK-Technological Pedagogical Content Knowledge. An article. (http://mkoehler.educ.msu.edu/tpack/pedagogical-knowledge-pk/_downloaded on January $27^{\text {th }}, 2014$, at 01.55 )

Lamb, Martin Veevers. 2007. The Motivation of Junior High School Pupils to Learn English in Provincial Indonesia. Dissertation. School of Education, The University of Leeds: Leeds.

Meador, Derrick. 2014. Personality Types of Students in a Typical Classroom. An article. (Online). http://teaching.about.com/od/pd/a/Personality-Types-OfStudents-In-ATypical-Classroom.htm (accessed on February 21 $1^{\text {st }}, 2014$ at 17.27)

Montgomery, Susan M. \& Groat, Linda N. 1998. Students Learning Styles and Their Implication for Teaching. Paper. The Center for Research in Learning and Teaching, The University of Michigan: Ann Arbor.

Mullock, Barbara. 2003. What makes a good teacher? the perceptions of postgraduate TESOL students. An article. Prospect, Vol. 18, No. 3, December 2003. The University of New South Wales, Sydney, Australia.

Musthafa, Bachrudin. 2010. Teaching English to young Learners in Indonesia: Essential Requirements. An article. Educationist, Vol. IV, No. 2, July 2010.

Norris, Simpson. 1999. Language Teacher Proficiency or Teacher Language Proficiency. An Environmental Scan of Information Relating to the Competencies/Qualities/Knowledges Required to be an Effective Language

Teacher. A Report Prepared for the Nalsas Taskforce. 
(http://www1.curriculum.edu.au/nalsas/pdf/language.pdf downloaded on January $26^{\text {th }}, 2014$, at 16.16 )

Nunan, David. 1992. Research Methods in Language Learning. Cambridge: Cambridge University Press.

O’Brien, L. 1990. Learning Channel Preference Checklist (LCPC). Rockville, MD: Spesific Diagnostic Service.

Peraturan Menteri Pendidikan Republik Indonesia, Nomor 16 Tahun 2007 tentang Standar Kualifilasi Akademik dan Kompetensi Guru.

Phern, Corinne Vong Siu. \& Abidin, Mohammad Jafre Zainol. 2012. Student Voice Contribution in Determining the Effective English Language Teacher: A Collective Case Study as a Concept Paper. An article. International Journal of Humanities and Social Science, Vol. 2, No. 22, Special Issue-November 2012.

Pollard, Andrew. 2010. Professionalism and Pedagogy: A contemporary opportunity. A commentary by Teaching and Learning Research Programme (TLRP) and General Teaching Council for England (GTC), Institute of Education, University of London: London.

Reid, J. 1995. Learning styles in the ESL/EFL classroom. Boston, MA: Heinle and Heinle Publishers.

Sesek, Urska. 2007. English for Teachers of EFL-Toward a Holistic Description. An article. English for Specific Purposes Journal, 26 (2007), 411-425. Published by Elsevier Ltd. The American University.

Shulman, Lee S. 1987. Knowledge and Teaching: Foundations of the New Reform. An article. Harvard Educational Review, Vol. 57, No. 1, February 1987.

Solis, Adela. 2009. Pedagogical Content Knowledge: What Matters Most in the Professional Learning of Content Teachers in Classroom with Diverse Student

Populations. IDRA-Intercultural Development Research Association. (Online). An Article.

http://www.idra.org/IDRA_Newsletter/August_2009_Actionable_Knowledge/Pedag ogical_Content_Knowledge/ accessed on January 27, 2014, at 01.59)

Sugiyono. 2012. Metode Penelitian Kombinasi (Mixed Method). Bandung: Alfabeta Bandung.

Tellis, Winston. 1997. Introduction to Case Study (online). The Qualitative Report, Volume 3, Number 2 (http://www.nova.edu/ssss/QR/QR3-2/tellis1.html, accessed at 9 December 2013)

The Association of Teachers of English as a Foreign Language (TEFLIN). 2011. Pernyataan Kebijakan: Tentang Pengajaran Bahasa Inggris di Indonesia. A paper. Universitas Pendidikan Indonesia: Bandung.

Thompson, Susan., Geer, John G., \& Geer, Bonnie B., 2004. Highly qualified for successful teaching: Characteristics every teacher should possess. An article. Download at http://www.usca.edu/essays/vol102004/thompson.pdf vol. 10, 2004. The University of Memphis.

Undang-Undang Republik Indonesia Nomor 14 Tahun 2005 Tentang Guru dan Dosen. Departemen Pendidikan Nasional. 
Undang-Undang Republik Indonesia Nomor 20 Tahun 2003 Tentang Sistem Pendidikan Nasional. Departemen Pendidikan Nasional.

Walgito, Bimo, 1991. Psikologi Sosial (Suatu Pengantar). Yogyakarta: Andi Offset.

Wichadee, Saovapa. 2009. Defining the Effective English Language Teacher: Students and Teachers' Perspective http:/www.bu.ac.th/knowledgecenter/epaper/ jan_june2010/pdf/Page_01.pdf JALT Annual Conference, (21-23 November 2009) Shuzouka, Japan.

Wichadee, Saovapa. 2011. Professional Development: A path to Success for EFL Teachers. An article. Contemporary Issue In Education Research, May 2011, Vol. 4, No. 5. 